\title{
PJTEL Editorial 2019-2021
}

Thomas Cochrane

Cochrane.t@unimelb.edu.au

University of Melbourne, Victoria, Australia.

Vickel Narayan

V.Narayan@massey.ac.nz

Massey University, New Zealand.

Helen Sissons

Helen.sissons@aut.ac.nz

Auckland Univesity of Technology

In this first editorial for the Pacific Journal of Technology Enhanced Learning, PJTEL, the lead editors reflect upon the first three years of the journal and explore the impact statistics. We also explore future directions and themes for the journal particularly in light of the impact of COVID19 on education.

Keywords: Altmetrics, Impact, Technology Enhanced Learning

\section{Introduction}

The Pacific Journal of Technology Enhanced Learning (PJTEL) was launched in 2019 alongside the second annual SoTEL Symposium (https://sotel.nz). PJTEL was one of the first ten fully open access, peerreviewed journals published by Tuwhera, Auckland University of Technology's (AUT) publishing platform hosted by the AUT Library based upon the Open Journal System (OJS). The founding editors identified a gap in the availability of fully open access journals focusing upon educational technology and the scholarship of technology enhanced learning, particularly in the Asia-Pacific region, with the few existing highly established open access educational technology journals providing limited pathways for supporting new and emerging researchers in the field and reticent to explore alternative metrics impact factors. PJTEL uses a Creative Commons licence (CC-BY-NC 4.0) and was established to:

\begin{abstract}
promote informed use of technology in learning and teaching - the scholarship of technology enhanced learning (SoTEL). In particular, empirical research that grows current understanding and application of the affordances of technology for improved pedagogical practice and student learning outcomes.
\end{abstract}

To provide new and emerging, as well as, experienced researchers an open access platform to share their findings and discourse. In particular, to build research capability locally by nurturing communities of practice (research clusters) and to provide equitable access to research and publications in the Pacific (https://ojs.aut.ac.nz/pjtel/about).

The first issue of PJTEL featured two full papers (Blaschke \& Hase, 2019; Cowie \& Sakui, 2019b), while the second and following issues of PJTEL have featured both full papers and SoTEL Symposium doubleblind peer-reviewed abstracts. A total of 6 full papers and 69 SoTEL Symposium abstracts were published between 2019 and the end of 2021.

The impact of COVID19.

Establishing a new educational technology journal during the 2020-2021 COVID19 pandemic has been a significant challenge. The editorial board of PJTEL is small (https://ojs.aut.ac.nz/pjtel/about/editorialTeam) and the reviewer pool is also relatively small, with 66 registered reviewers, 10 of whom have been most active.

\section{Background}


PJTEL is founded upon the principles of double-blind peer review, open access publishing and alternative impact factors, we explore open access and altmetrics in this section.

\section{Open Access Publishing}

Government funding agencies argue for public access to publicly funded research (European Commision, 2016; Higher Education Funding Council for England (hefce), 2015). Fully open access educational technology journals are rare, with a few notable high impact factor examples (Olijhoek, 2015; Veletsianos, 2009). Fully open access journals without Article Publishing Charges (APCs) are generally funded by a sponsoring institution or professional society. These journals rely upon editorial board members and reviewers donating their time for free and have limited budgets for the on-going costs associated with journal publishing - DOI registration costs, web-hosting, metrics subscriptions etc... This academic activity has been highly valued but hard to demonstrate for purposes such as promotion or evidence of international impact. While ORCID (Open Researcher and Contributor Identity) has become established as a platform for individual academic output eportfolios, PUBLONs facilitates an eportfolio for review and editorial activity (https://publons.com/journal/399792/pacific-journal-of-technology-enhanced-learning/). The lead editors of PJTEL have argued for updating Boyer's (Boyer, 1990) concept of SOTL (Scholarship Of Teaching and Learning) for the $21^{\text {st }}$ century to integrate TEL (Technology Enhanced Learning) and professional online research profiles (Cochrane \& Narayan, 2018).

The Open Journal System (https://pkp.sfu.ca/ojs/) is an open source software platform that was established in 2001 to support open access publishing. OJS has become widely used for over 25000 open access journals.

PJTEL was included in the list of open access journals in educational technology curated by Weidlich (2019), the list included 18 journals in 2019 with 24 included in a 2021 update. Weidlich summarises PJTEL's contribution to the list of open access educational technology journals:

This new journal is published by the Centre for Teaching and Learning from Auckland University of Technology, New Zealand. The editorial team is looking for submissions of between 4000 and 6000 words but also accept up to 8000 words. Authors are provided with a formatting template. PJTEL is aiming for two issues per year with continuous publication. As the journal is still very new, the editors are still working on building their review base. The journal website also provides a forum for discussions, sharing of material and questions regarding submissions. (https://joshuaweidlich.wordpress.com/2019/06/05/open-accessjournals-in-educational-technology/).

\section{Impact metrics}

Traditional journal impact factors are generated by article download, read and citation statistics. Altmetrics - Alternative Metrics, provide a faster indication of the potential impact of published research than the timeframe associated with traditional citation metrics (Cochrane et al., 2018; Haustein, 2018; Williams \& Padula, 2015; Wouter, 2016). Analysis of the correlation between aggregated altmetric attention scores and traditional citations indicates a strong positive correlation (Lamba, 2020). PJTEL has enabled the PlumX OJS plugin for published article altmetrics.

\section{PlumX}

PlumX (https://plumanalytics.com) is one form of the many altmetrics platforms now available for providing alternative impact metrics for journal contributions (Cochrane, 2020). PlumX was acquired by Elsevier publishing in 2017. PlumX Metrics and an embeddable widget are provided free of charge to noncommercial open access journals and regional repositories, with an OJS plugin freely available. PlumX curates impact statistics through citations, usage, captures (e.g. Mendeley reads), mentions (Blog posts, Wikipedia, Media...), and social media (Twitter, Facebook, Vimeo, YouTube, Amazon, Figshare, Reddit).

Figshare

Parallel to the development of alternative metrics for research publication has been the development of alternative publishing platforms to support research outputs beyond traditional journal articles. Figshare (https://figshare.com/about) was developed to enable the publication and archiving of digital artifacts 
including digital posters, presentations, datasets and code, disseminated using DOIs with curation links to ORCID as well as Scopus and Web Of Science databases and altmetrics platforms. Figshare therefore enables impact measures for alternative forms of publishing (Cochrane, 2020). Throughout 2020 the \#Datacreativities project (Belton et al., 2020; Cochrane et al., 2021a; Coleman et al., 2021; Spreadborough et al., 2021) developed a transdisciplinary framework for data visualisation utilising Figshare that was used as a model to publish the SoTEL 2021 Symposium Pecha Kucha presentations (Cochrane et al., 2021b).

\section{Statistical Analysis of Submissions}

In this section we explore the statistics and implications of impact of submissions to PJTEL to date.

\section{Summary statistics}

Summary trends were generated by the OJS report generator for 2019 to the end of 2021 (Table 1). Altmetrics impact for full articles and top 20 reported articles and abstracts were generated by the OJS PlumX altmetrics plugin.

Table 1: PJTEL OJS Editorial Report Summary

\begin{tabular}{|l|l|l|l|}
\hline Trend & Total & $\begin{array}{l}\text { Full } \\
\text { Papers }\end{array}$ & $\begin{array}{l}\text { SoTEL } \\
\text { Abstracts }\end{array}$ \\
\hline Submissions Received & 98 & 8 & 90 \\
\hline Submissions Accepted & 75 & 6 & 69 \\
\hline Submissions Declined & 17 & & \\
\hline Submissions Declined (Desk Reject) & 7 & & \\
\hline Submissions Declined (Post-Review) & 9 & & \\
\hline Submissions Declined (Other) & 1 & & 69 \\
\hline Submissions Published & 75 & 6 & \\
\hline Average Days to First Editorial Decision & 2 & & \\
\hline Average \# Days to Accept & 39 & & \\
\hline Average \# Days to Reject & 22 & & \\
\hline Acceptance Rate & $76.53 \%$ & $75 \%$ & \\
\hline Rejection Rate & $17.35 \%$ & & \\
\hline Desk Reject Rate & $7.14 \%$ & & \\
\hline Post-Review Reject Rate & $9.18 \%$ & & \\
\hline Other Reject Rate & $1.02 \%$ & & \\
\hline
\end{tabular}

Table 2 shows the Top 20 articles views, downloads and PlumX metrics (Full articles highlighted)

Table 2: Top 20 PJTEL articles OJS Report

\begin{tabular}{|l|l|l|l|l|}
\hline Author and Title & $\begin{array}{l}\text { Abstract } \\
\text { views }\end{array}$ & $\begin{array}{l}\text { PDF } \\
\text { downloads }\end{array}$ & Total & PlumX \\
\hline $\begin{array}{l}\text { (Blaschke \& Hase, 2019) Heutagogy and digital media } \\
\text { networks: Setting students on the path to lifelong learning }\end{array}$ & 2053 & 1657 & 3710 & 67 \\
\hline $\begin{array}{l}\text { (Singleton \& Charlton, 2019) Creating H5P content for } \\
\text { active learning }\end{array}$ & 1607 & 1350 & 2957 & 50 \\
\hline $\begin{array}{l}\text { (Thomas, 2019) Teacher and student experiences in } \\
\text { learning: Google Education Apps }\end{array}$ & 522 & 318 & 840 & 54 \\
\hline $\begin{array}{l}\text { (Cochrane \& Munn, 2020) Integrating Educational } \\
\text { Design Research and Design Thinking to Enable Creative } \\
\text { Pedagogies }\end{array}$ & 491 & 319 & 810 & 12 \\
\hline $\begin{array}{l}\text { (Pham et al., 2020) Natural language processing for } \\
\text { analysis of student online sentiment in a postgraduate } \\
\text { program }\end{array}$ & 479 & 197 & 676 & 11 \\
\hline $\begin{array}{l}\text { (Cochrane \& Sissons, 2020) An Introduction to } \\
\text { Immersive Reality }\end{array}$ & 378 & 227 & 605 & 6 \\
\hline $\begin{array}{l}\text { (Clune, 2019b) Digital Escape Game: Breaking out of a } \\
\text { mathematical medley }\end{array}$ & 342 & 255 & 597 & 2 \\
\hline
\end{tabular}




\begin{tabular}{|l|l|l|l|l|}
\hline $\begin{array}{l}\text { (Ramirez, 2021) The need to provide students and } \\
\text { educators with the tools to cross the digital divide }\end{array}$ & 350 & 246 & 596 & 3 \\
\hline $\begin{array}{l}\text { (Clune, 2019a) Digital Badging in CANVAS: } \\
\text { Synthesising course content, readings and experiences }\end{array}$ & 343 & 221 & 564 & 0 \\
\hline $\begin{array}{l}\text { (Sinfield \& Cochrane, 2020) A framework for re } \\
\text { thinking the pedagogy of studio-based design classrooms }\end{array}$ & 316 & 216 & 532 & 13 \\
\hline $\begin{array}{l}\text { (Kaur, 2019) Incorporating immediate feedback in } \\
\text { formative learning checks using H5P }\end{array}$ & 318 & 201 & 519 & 7 \\
\hline $\begin{array}{l}\text { (Sissons \& Cochrane, 2019) Introducing Immersive } \\
\text { Reality into the Journalism Curriculum }\end{array}$ & 279 & 211 & 490 & 8 \\
\hline $\begin{array}{l}\text { (Cowie \& Sakui, 2019a) Enhancing student retention } \\
\text { rates on open non-formal online language learning } \\
\text { courses }\end{array}$ & 255 & 234 & 489 & 6 \\
\hline $\begin{array}{l}\text { (Cochrane \& Narayan, 2019) A Model for Developing a } \\
\text { SOTEL Research Cluster: MESH360 }\end{array}$ & 325 & 160 & 485 & 4 \\
\hline $\begin{array}{l}\text { (Murphy, 2019) Media-Multitasking: The dark side of } \\
\text { technology use within University learning contexts }\end{array}$ & 244 & 237 & 481 & 49 \\
\hline $\begin{array}{l}\text { (Schwenger, 2019) Creating blended learning } \\
\text { experiences requires more than digital skills: Developing } \\
\text { staff skills in the effective use of technology to enhance } \\
\text { student learning }\end{array}$ & 259 & 202 & 461 & 4 \\
\hline $\begin{array}{l}\text { (Macdiarmid et al., 2019) Exploring case based clinical } \\
\text { learning in graduate-entry nursing }\end{array}$ & 233 & 184 & 417 & 4 \\
\hline $\begin{array}{l}\text { (Devine, 2020) Reflections on the use of Design Thinking } \\
\text { and Service Design Tools to Improve Student Experience } \\
\text { of an Online Learning Environment }\end{array}$ & 205 & 181 & 386 & 5 \\
\hline $\begin{array}{l}\text { (Cowie \& Sakui, 2019b) Enhancing student retention } \\
\text { rates on open non-formal online language learning } \\
\text { courses }\end{array}$ & 214 & 171 & 385 & 2 \\
\hline $\begin{array}{l}\text { (Cochrane \& Sinfield, 2019) A Model for Designing } \\
\text { Authentic Learning: Summer Student Scholarships }\end{array}$ & 180 & 202 & 382 & 6 \\
\hline
\end{tabular}

Total Impact Statistics for full articles (Downloads, Reads, PlumX Metrics, Google Scholar (GS) Citations) are curated in Table 3.

Table3: PJTEL Full Papers Impact Statistics Summary

\begin{tabular}{|c|c|c|c|c|c|}
\hline Articles by date and Section & Views & Downloads & $\begin{array}{l}\text { PlumX } \\
\text { Captures }\end{array}$ & $\begin{array}{l}\text { PlumX } \\
\text { Tweets }\end{array}$ & $\begin{array}{l}\text { GS } \\
\text { Citations }\end{array}$ \\
\hline (Blaschke \& Hase, 2019) & 2053 & 1657 & 35 & 30 & 45 \\
\hline (Cowie \& Sakui, 2019b) & 214 & 171 & 2 & 0 & 3 \\
\hline (Cochrane \& Munn, 2020) & 491 & 319 & 7 & 5 & 6 \\
\hline (Pham et al., 2020) & 479 & 197 & 8 & 3 & 0 \\
\hline (Sinfield \& Cochrane, 2020) & 316 & 216 & 5 & 8 & 6 \\
\hline (Perry \& Probine, 2021) & 127 & 48 & 0 & 4 & 0 \\
\hline TOTAL & 3680 & 2608 & 57 & 50 & 60 \\
\hline
\end{tabular}

\section{Thematic Analysis}

The most popular topics explored in PJTEL submissions include:

- Online Learning (21)

- Mobile learning (16 articles)

- Pedagogy and Learner Agency (13 articles)

- Immersive reality (8 articles)

- Design-Based Research (6) 
- Heutagogy (5 articles)

The PJTEL editorial board and reviewer pool share close relationships with the ASCILITE community (Australasian Society for Computers In Learning In Tertiary Education) and particularly the ASCILITE Mobile Learning Special Interest Group (\#ASCILITEMLSIG), hence the most popular themes/topics are unsurprising.

\section{Research methodologies}

Articles and abstracts published in PJTEL include quantitative and qualitative research methodologies as well as position papers. SoTEL Symposium abstracts feature a dialogue between research and practice in education. Design-based research is a central theme across many of the research methods in PJTEL articles.

\section{Discussion}

Impact of PJTEL publications.

The OJS statistics show the impact of the 75 articles published in PJTEL between February 2019 and January 2022. In comparison to an established Q1 ranked journal such as AJET (Australasian Journal of Educational Technology), PJTEL's article acceptance rate is very high as the journal establishes itself as a platform for scholarly publication and dissemination of research (AJET acceptance rate from 2143 submissions $2019-02-18$ to $2022-01-16=8 \%$ compared to $76.53 \%$ for 98 submissions to PJTEL). However, the top views for articles over that period reveals PJTEL as a new and establishing journal significantly 'punches above its weight' (Table 4).

Table 4: Comparison of Top article statistics published after 2019-02-18

\begin{tabular}{|l|l|l|l|l|}
\hline Author and Title & $\begin{array}{l}\text { Abstract } \\
\text { views }\end{array}$ & $\begin{array}{l}\text { PDF } \\
\text { downloads }\end{array}$ & Total & Journal \\
\hline $\begin{array}{l}\text { (Blaschke \& Hase, 2019) Heutagogy and digital media } \\
\text { networks: Setting students on the path to lifelong } \\
\text { learning }\end{array}$ & 2053 & 1657 & 3710 & PJTEL \\
\hline $\begin{array}{l}\text { (Bhagat et al., 2019) The impact of personality on } \\
\text { students' perceptions towards online learning }\end{array}$ & 5266 & 6267 & 11533 & AJET \\
\hline
\end{tabular}

Google analytics recorded 3663 page views for PJTEL during 2021. OJS recorded a peak of just over 1200 abstract views between 2019 and 2021 with the peak coinciding with the February 2021 SoTEL Symposium (Figure 1).

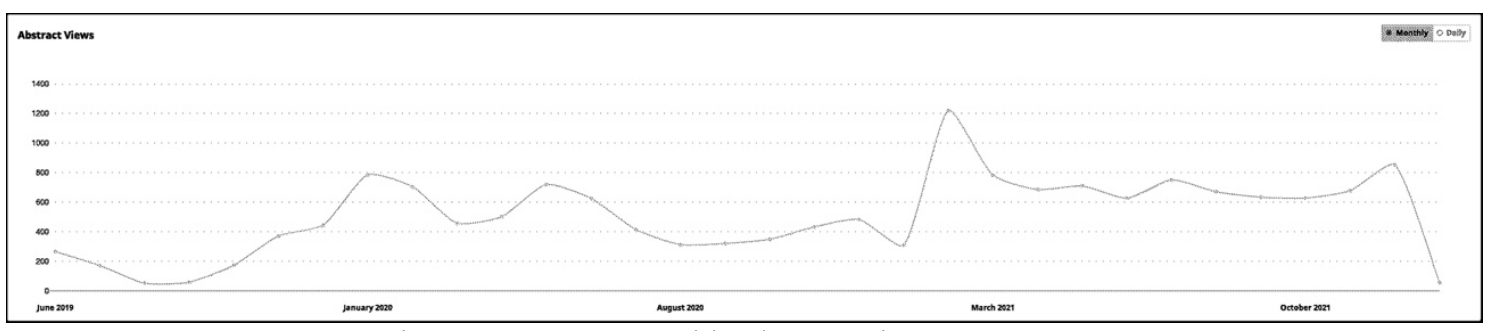

Figure 1: PJTEL monthly abstract views 2019-2021.

There is a general correlation between altmetrics (PlumX) and article views and downloads (Table 2 and Table 3). The main PlumX metrics evidenced are through Twitter mentions and Mendeley reads.

Supporting the development of the SoTEL Community

PJTEL was initially established to support the development of a SoTEL research community in New Zealand (https://sotel.nz) and has grown to support an Australasian SoTEL research community (https://blogs.unimelb.edu.au/sotel/) through five iterations of the annual SoTEL Symposium as well as 3 full paper issues of PJTEL - admittedly full paper articles published are a small number, averaging 2 per annum, however the intention is to grow this aspect of PJTEL in the future. 
Full paper impact

While there is currently a high acceptance rate for PJTEL submissions ( $76 \%$, Table1) these have arguably been of high quality for a new and emerging journal. This is illustrated by the impact statistics of the top full paper published in PJTEL so far (Blaschke \& Hase, 2019).

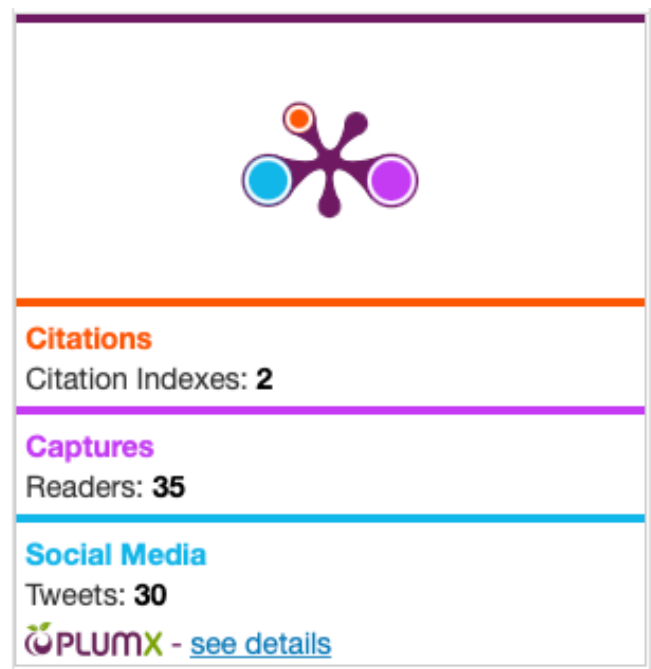

Figure 2: PlumX metrics for Blaschke and Hase (2019)

Figure 2 and Figure 3 summarise the metrics data for Blaschke and Hase (2019). Blaschke and Hase are both established authors in the field of heutagogy. Their paper was the first full article published by PJTEL and currently has the top impact metrics of all the articles published in PJTEL. With 45 citations recorded via Google Scholar the article is the highest cited article published in 2019 by both Blaschke and Hase with citations in Q1 and Q2 ranked journals such as BJET (Lock et al., 2021), the International Journal of Educational Technology in Higher Education (Lynch et al., 2021) and RLT (Cochrane, Aiello, et al., 2020; Cochrane, Birt, et al., 2020). 


\section{Downloads}

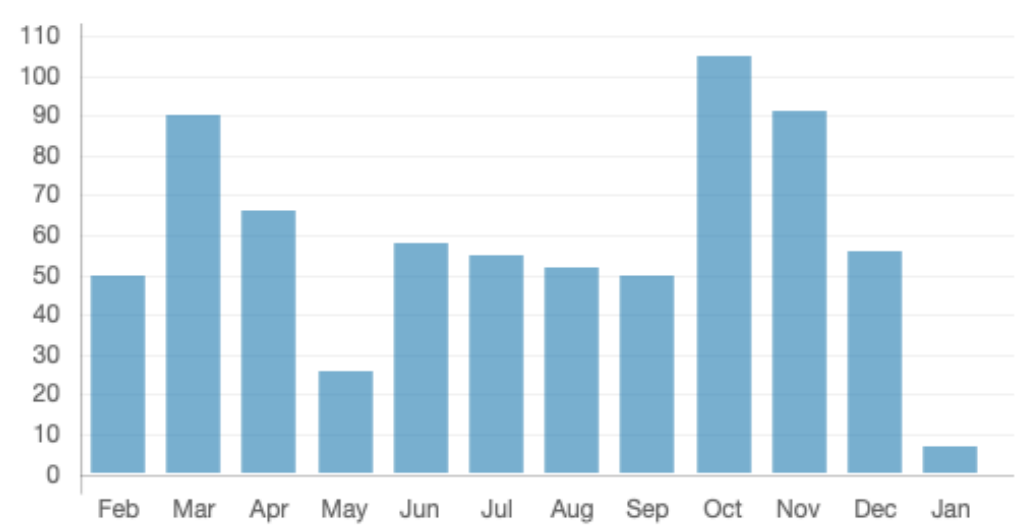

\section{Metrics}

\section{PDF views}

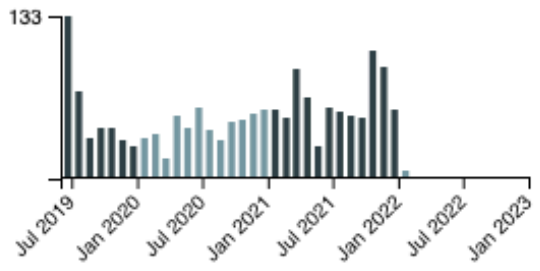

\section{Twitter}

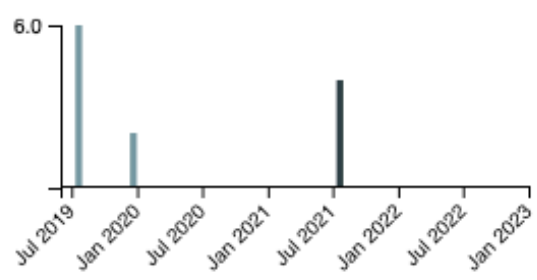

daily (first 30) | monthly | yearly

\section{Wordpress.com}

Figure 3. Summary metrics from OJS for Blaschke and Hase (2019)

PJTEL and the COVID 19 pandemic.

There is a clear correlation between the top five articles published in PJTEL and the pandemic. The statistics are perhaps driven by the sudden need for academics to upskill on certain design and consideration elements for pivoting to or facilitating a course either online or in a blended mode. The 2019 article from Blaschke and Hase dwells on design elements for learner agency, a critical principle for facilitating learning and teaching during the pandemic. Similarly, Singleton and Charlton's (2019) 
article provides insights into using H5P for developing online interactive learning content and Thomas' (2019) article discusses the use of Google Apps for education as a learning platform. The pandemic related theme in 2020 seems to have moved on from the need to create content to a more considered approach for doing the same. For example, Cochrane and Munn's article (2020) discusses design-based research and thinking as a framework for envisioning and applying innovative digital pedagogies. Continuing with the theme, Pham et al., (2020) provide a student focus for designing for online learning and discuss the attitudes and emotional factors that determine and guide the learner's engagement and behaviour in an online environment.

\section{Future Directions}

Ticking the box for achieving a journal ranking for PJTEL.

Areas needing addressing for future inclusion of PJTEL in the Scopus and Web of Science citation databases include: frequency of publication, more detailed publication ethics statement, timeliness of reviews and publication of articles, increasing international editorial board memberships.

\section{Conclusion}

PJTEL has established a publication platform that supports and mentors fully open access educational technology research and practice with a focus upon enabling alternative metrics and publication formats. We look forward to growing the journal and its impact over the next few years.

\section{Statement on open data, ethics and conflict of interest}

The journal provides open access to all of its content on the principle that making research freely available to the public supports a greater global exchange of knowledge (Weller, 2014). Such access is associated with increased readership and increased citation of an author's work (Niyazov et al., 2016). All articles are made available using a Creative Commons (CC-BY-NC 4.0) internationally shareable licence, meaning that content may be shared worldwide but the source must be acknowledged appropriately. However, the licence excludes the right to create derivatives (for more details please see https://creativecommons.org/licenses/by-nc/4.0/). PJTEL does not charge any fees for submission, publication or access to articles. PJTEL follows AUT's ethical content procedures (https://www.aut.ac.nz/research/researchethics).

\section{References}

Belton, A., Cochrane, T., Coleman, K., Fitzgerald, E., Glasser, S., Melzack, G., Spreadborough, K., \& Sweeney, D. (2020). Digital Methods for research led T\&L practices in the COVID new normal: a workshop exploring findings from a MDAP Collaboration between MGSE, SCIP, FFAM, and CSHE during 'lockdown'. https://omeka.cloud.unimelb.edu.au/datacreative/workshop2020

Bhagat, K. K., Wu, L. Y., \& Chang, C.-Y. (2019). The impact of personality on students' perceptions towards online learning. Australasian Journal of Educational Technology, 35(4). https://doi.org/10.14742/ajet.4162

Blaschke, L. M., \& Hase, S. (2019). Heutagogy and digital media networks: Setting students on the path to lifelong learning. Pacific Journal of Technology Enhanced Learning, 1(1), 1-14. https://doi.org/10.24135/pjtel.v1i1.1

Boyer, E. (1990). Scholarship reconsidered: priorities of the professoriate. Carnegie Foundation for the Advancement of Teaching.

Clune, M. L. (2019a). Digital Badging in CANVAS: Synthesising course content, readings and experiences. Pacific Journal of Technology Enhanced Learning, 2(1), 1. https://doi.org/10.24135/pjtel.v2i1.18

Clune, M. L. (2019b). Digital Escape Game: Breaking out of a mathematical medley. Pacific Journal of Technology Enhanced Learning, 2(1), 4. https://doi.org/10.24135/pjtel.v2i1.19

Cochrane, T. (2020). Altmetrics and Social Media: Amplifying research impact. https://doi.org/10.6084/m9.figshare.13356608.v1

Cochrane, T., Aiello, S., Cook, S., Aguayo, C., \& Wilkinson, N. (2020). MESH360: A framework for designing MMR enhanced Clinical Simulations [Journal]. Research in Learning Technology, 28(Mobile Mixed Reality - Themed Collection). https://doi.org/10.25304/rlt.v28.2357 
Cochrane, T., Birt, J., \& Narayan, V. (2020). Editorial for 2019 update to the RLT special collection on mobile mixed reality [Journal]. Research in Learning Technology, 28(Special Collection). https://doi.org/10.25304/rlt.v28.2424

Cochrane, T., Coleman, K., Belton, A., Fitzgerald, E., Glasser, S., Harris, J., Melzack, G., Spreadborough, K., \& Mactavish, K. (2021a). \#DataCreativities: Developing a trans-disciplinary data visualization framework from Arts practice to teaching and learning during COVID19. Pacific Journal of Technology Enhanced Learning, 3(1), 8-10. https://doi.org/10.24135/pjtel.v3i1.84

Cochrane, T., Coleman, K., Belton, A., Fitzgerald, E., Glasser, S., Harris, J. O., Melzack, G., Spreadborough, K., \& MacTavish, K. (2021b, 18 February). \#DataCreativities: Developing a trans-disciplinary data visualization framework from Arts practice to teaching and learning $\begin{array}{lll}\text { during COVID19 SoTEL2021, } & \end{array}$ https://figshare.com/articles/media/_DataCreativities_Developing_a trans-

disciplinary data_visualization_framework_from_Arts practice to teaching_and learning_duri ng_COVID19/13726870

Cochrane, T., \& Munn, J. (2020). Integrating Educational Design Research and Design Thinking to Enable Creative Pedagogies. Pacific Journal of Technology Enhanced Learning (PJTEL), 2(2), 1-14. https://doi.org/10.24135/pjtel.v2i2.58

Cochrane, T., \& Narayan, V. (2018, 25-29 June, 2018). The Scholarship of Technology Enhanced Learning: Reimagining SOTL for the Social Network Age. EdMedia: World Conference on Educational Media and Technology 2018, Amsterdam, Netherlands.

Cochrane, T., \& Narayan, V. (2019). A Model for Developing a SOTEL Research Cluster: MESH360. Pacific Journal of Technology Enhanced Learning, 2(1), 11-12. https://doi.org/https://doi.org/10.24135/pjtel.v2i1.31

Cochrane, T., Redmond, P., \& Corrin, L. (2018). Technology Enhanced Learning, Research Impact and Open Scholarship. Australasian Journal of Educational Technology, 34(3), i-viii. https://doi.org/10.14742/ajet.4640

Cochrane, T., \& Sinfield, D. (2019). A Model for Designing Authentic Learning: Summer Student Scholarships. Pacific Journal of Technology Enhanced Learning, 2(1), 8. https://doi.org/10.24135/pjtel.v2i1.29

Cochrane, T., \& Sissons, H. (2020). An Introduction to Immersive Reality. Pacific Journal of Technology Enhanced Learning, 2(1), 6. https://doi.org/10.24135/pjtel.v2i1.28

Coleman, K., Spreadborough, K., Belton, A., \& Cochrane, T. (2021, 8-9 April). 'Mixed-tape Methods'for Data in Post-digital Times of Disease Seventeeth International conference on Technology Knowledge and Society - Considering Viral Technologies: Pandemic-Driven Opportunities and Challenges, University of Melbourne, Melbourne, Australia. https://cgscholar.com/cg_event/events/T21/proposal/54372

Cowie, N., \& Sakui, K. (2019a). Enhancing student retention rates on open non-formal online language learning courses. Pacific Journal of Technology Enhanced Learning, 2(1), 25-26. https://doi.org/10.24135/pjtel.v2i1.26

Cowie, N., \& Sakui, K. (2019b). Enhancing student retention rates on open non-formal online language learning courses. Pacific Journal of Technology Enhanced Learning, 1(1), 15-24. https://doi.org/10.24135/pjtel.v1i1.17

Devine, P. T. (2020). Reflections on the use of Design Thinking and Service Design Tools to Improve Student Experience of an Online Learning Environment. Pacific Journal of Technology Enhanced Learning, 2(1), 51. https://doi.org/10.24135/pjtel.v2i1.62

European Commision. (2016). Open Access. European Commission: Research \& Innovation. http://ec.europa.eu/research/openscience/index.cfm?pg=openaccess

Haustein, S. (2018). Scholarly Twitter metrics. In W. Glanzel, H.F. Moed, U. Schmoch, \& M. Thelwall (Eds.), Handbook of Quantitative Science and Technology Research. https://arxiv.org/abs/1806.02201

Higher Education Funding Council for England (hefce). (2015). Open access research. Retrieved 24 February 2016 from http://www.hefce.ac.uk/rsrch/oa/

Kaur, K. (2019). Incorporating immediate feedback in formative learning checks using H5P. Pacific Journal of Technology Enhanced Learning, 2(1), 34. https://doi.org/10.24135/pjtel.v2i1.42

Lamba, M. (2020). Research productivity of health care policy faculty: a cohort study of Harvard Medical School. Scientometrics, 124(1), 107-130. https://doi.org/10.1007/s11192-020-03433-5 
Lock, J., Lakhal, S., Cleveland-Innes, M., Arancibia, P., Dell, D., \& De Silva, N. (2021). Creating technology-enabled lifelong learning: A heutagogical approach. British Journal of Educational Technology.

Lynch, M., Sage, T., Hitchcock, L. I., \& Sage, M. (2021). A heutagogical approach for the assessment of Internet Communication Technology (ICT) assignments in higher education. International Journal of Educational Technology in Higher Education, 18(1), 55. https://doi.org/10.1186/s41239-021-00290-x

Macdiarmid, R., Winnington, R., \& Merrick, E. (2019). Exploring case based clinical learning in graduateentry nursing. Pacific Journal of Technology Enhanced Learning, 2(1), 29-30. https://doi.org/10.24135/pjtel.v2i1.57

Murphy, K. (2019). Media-Multitasking: The dark side of technology use within University learning contexts. Pacific Journal of Technology Enhanced Learning, 2(1), 19. https://doi.org/10.24135/pjtel.v2i1.35

Niyazov, Y., Vogel, C., Price, R., Lund, B., Judd, D., Akil, A., Mortonson, M., Schwartzman, J., \& Shron, M. (2016). Open Access Meets Discoverability: Citations to Articles Posted to Academia.edu. PLOS ONE, 11(2), 1-23. https://doi.org/10.1371/journal.pone.0148257

Olijhoek, T. (2015). Directory of Open Access Journals. Cottage Labs LLC. Retrieved 10 November from https://doaj.org

Perry, J., \& Probine, S. (2021). Reconceptulising the Role of the Visiting Lecturer: : Using Educational Technology to Enable Practicum Placements in the 'New Normal'. Pacific Journal of Technology Enhanced Learning, 3(2), 1-9. https://doi.org/10.24135/pjtel.v3i2.111

Pham, T. D., Vo, D., Li, F., Baker, K., Han, B., Lindsay, L., Pashna, M., \& Rowley, R. (2020). Natural language processing for analysis of student online sentiment in a postgraduate program. Pacific Journal of Technology Enhanced Learning, 2(2), 15-30. https://doi.org/10.24135/pjtel.v2i2.4

Ramirez, E. (2021). The need to provide students and educators with the tools to cross the digital divide. Pacific Journal of Technology Enhanced Learning, 3(1), 22-23. https://doi.org/10.24135/pjtel.v3i1.94

Schwenger, B. K. (2019). Creating blended learning experiences requires more than digital skills: Developing staff skills in the effective use of technology to enhance student learning. Pacific Journal of Technology Enhanced Learning, 2(1), 35. https://doi.org/10.24135/pjtel.v2i1.46

Sinfield, D., \& Cochrane, T. (2020). A framework for re thinking the pedagogy of studio-based design classrooms. Pacific Journal of Educational Technology (PJTEL), 2(2), 31-44. https://doi.org/10.24135/pjtel.v2i2.77

Singleton, R., \& Charlton, A. (2019). Creating H5P content for active learning. Pacific Journal of Technology Enhanced Learning, 2(1), 13-14. https://doi.org/10.24135/pjtel.v2i1.32

Sissons, H., \& Cochrane, T. (2019). Introducing Immersive Reality into the Journalism Curriculum. Pacific Journal of Technology Enhanced Learning, 2(1), 7. https://doi.org/10.24135/pjtel.v2i1.27

Spreadborough, K., Cochrane, T., Glasser, S., Sweeney, D., Harris, J., Belton, A., Coleman, K., Melzack, G., \& Fitzgerald, E. (2021). CO-llaborative VI-rtual D-esign: A Collaborative Autoethnography on Conducting Exclusively Online, Data-Led Collaborations in the Creative Industries. Qualitative Inquiry, 1-17. https://doi.org/10.1177/10778004211039165

Thomas, C. E. (2019). Teacher and student experiences in learning: Google Education Apps. Pacific Journal of Technology Enhanced Learning, 2(1), 3. https://doi.org/10.24135/pjtel.v2i1.21

Veletsianos, G. (2009, 2013). Open Access Educational Technology journals. Retrieved 4 November from http://www.veletsianos.com/2009/08/09/open-access-educational-technology-journals/

Weidlich, J. (2019, 10 January). Open Access Journals in Educational Technology. Joshua Weidlich: Educational Technology. https://joshuaweidlich.wordpress.com/2019/06/05/open-accessjournals-in-educational-technology/

Weller, M. (2014). The Battle For Open: How openness won and why it doesn't feel like victory. Ubiquity Press. https://doi.org/http://dx.doi.org/10.5334/bam

Williams, C., \& Padula, D. (2015). The evolution of impact factors: From bibliometrics to altmetrics. Scholastica. http://docs.scholastica.s3.amazonaws.com/altmetrics/evolution-of-impactindicators.pdf

Wouter, G. (2016). Altmetrics a Primer.pdf. https://doi.org/10.6084/m9.figshare.3189256.v1 